\title{
Educar na alegria do amor: por um processo pastoral de iniciação à vida matrimonial à luz da Amoris Laetitia
}

Orientador: Abimar Oliveira de Moraes

Mestrando: Daniel Cipriano Peres

Área de Concentração: Teologia Sistemático-Pastoral

Linha de Pesquisa: Fé e Cultura

Projeto de Pesquisa: Ministérios de serviço: identidade, missão e contribuições pastorais

A família como escola de sociabilidade entre as pessoas permanece como lugar de aquisição de verdadeiros valores humanos através de um estilo fraterno de convivência possibilitando aos indivíduos a transmissão desses valores à sociedade. A família que nasce a partir da união do homem e da mulher, permanece muito valorizada, sobretudo, por parte daqueles que desejam se casar porque a reconhecem como instituição desejada e querida por Deus. Os esposos com seu amor e pela fé na graça do sacramento do matrimônio podem resplandecer o verdadeiro amor de Cristo pela Igreja. Dessa forma, é urgente por parte dos casais e de toda Igreja universal, empenhados numa atividade de evangelização, apresentar uma pastoral de formação e preparação à iniciação da vida matrimonial para que o Evangelho da família possa ser reconhecido como Evangelho de Cristo.

Palavras-chave: Família. Matrimônio. Amor. Conjugalidade. Pastoral. 